Original Article

\title{
ANALYSIS OF VIPAKA (METABOLIC TRANSFORMATION) OF AN EXTRA-PHARMACOPOEIAL DRUG-BRIDELIA STIPULARIS (L.) BLUME
}

\author{
HARITHA N1, SUDHAKAR BHAT2 ${ }^{2}$ N MANOJ KUMAR ${ }^{3}$
}

1,3Department of Dravyagunavijnana, V. P. S. V. Ayurveda College, Kottakkal, Kerala, ${ }^{2}$ Department of Pharmacology, SDM Centre for Ayurveda and Allied Sciences, Udupi, Karnataka

Email: harithamidhun@gmail.com

Received: 10 Oct 2019, Revised and Accepted: 14 Jan 2020

\section{ABSTRACT}

Objective: The objective of the present study is to explore the vipaka of an extra-pharmacopoeia drug Bridelia stipularis (L.) Blume belongs to the Euphorbiaceae family.

Methods: 12 Wistar strain albino rats were selected and divided into 2 groups; Group A-Control, Group B-Test group. Each rat was kept in separate metabolic cages provided with a constant amount of water and food per day. Assessment of vipaka was done based on the consumption of food, consumption of water, the quantity of faecal matter, urine output, and quantity of water content of expelled faecal matter per day. Assessment of Vipaka was done on the basis of consumption of food; consumption of water; the quantity of faecal matter, urine output and quantity water content of expelled faecal matter per day. Assessment of Vipaka was done on the basis of consumption of food; consumption of water; the quantity of faecal matter, urine output and quantity water content of expelled faecal matter per day.

Results: Absolute values of Group B or test group exhibited significant increase in water consumption $(\mathrm{p}<0.01)$, wet faecal matter ( $<<0.05)$, dry faecal matter $(\mathrm{p}<0.001)$, and food conversion ratio $(\mathrm{p}<0.05)$, and non-significant increase in food consumption, urine output, faecal water, and body weight.

Conclusion: Based on the preliminary analysis it may be concluded that the drug Bridelia stipularis (L.) Blume possess Madhura vipaka (Sweet metabolic transformation).

Keywords: Bridelia stipularis, Vipaka, Vipaka assessment

(C) 2020 The Authors. Published by Innovare Academic Sciences Pvt Ltd. This is an open access article under the CC BY license (http://creativecommons.org/licenses/by/4.0/) DOI: http://dx.doi.org/10.22159/ijpps.2020v12i3.36030. Journal homepage: https://innovareacademics.in/journals/index.php/ijpps

\section{INTRODUCTION}

Ayurvedic science has got an immense database of herbal drugs. It is becoming increasingly popular worldwide with many chronic conditions responding to it well. On the other hand, the scarcity of popular herbs makes a hindrance to meet this demand. Here arises the need for exploring extrapharmacopoeial drugs. Bridelia stipularis (L.) Blume is one of the extra-pharmacopoeial drugs having wide uses. It is a large woody evergreen climber or straggling shrub belonging to the family Euphorbiaceae and is distributed in South-east Asia like the central and eastern parts of Bangladesh, India, and Myanmar (Kritikar K R et al.,1975). Different parts of this plant are applicable for various treatments. Bark decoction is given to children for cough, fever, and asthma and as a gargle for sores in the mouth. Fresh tender leaves are used for the treatment of jaundice and anemia due to pregnancy [1]. Root extract along with the combination of other plant is used to treat herpes [2]. The decoction of wood is used in the treatment of Malaria disease [3].

Ayurvedic pharmacological properties or rasapancakas are the fundamental principles of Ayurveda based on which drug actions can be explained. So, for utilizing a new drug in Ayurveda based on Ayurvedic fundamental principles, the knowledge of Rasa (Taste), Guna (Property), Virya (Active potency), Vipaka (Metabolism) of the drug is mandatory. Since the ayurvedic pharmacological properties of Bridelia stipularis not yet been explored, the present study was conducted to assess the vipaka of the drug. Vipaka can be defined as the outcome of the biotransformation of the rasa (taste) of a dravya through the action of jatharagni [4]. Acarya Caraka well explained the action of vipāka on dośa, dhatu, and mala [5]. On this footing, an experiment was carried out and assessment of vipāka was done based on the consumption of food, consumption of water, the quantity of faecal matter, urine output, and quantity of water content of expelled faecal matter per day.

\section{MATERIALS AND METHODS}

\section{Plant material}

Bridelia stipularis (L.) Blume was collected from Chelari, Malappuram district, Kerala and authenticated from CMPR (Centre for Medicinal Plant Research), Aryavaidyasala, Kottakkal, Kerala, India (specimen no. CMPR10961).

\section{Preparation of leaf decoction}

The decoction was made by the conventional method of kwätha preparation as per Śärngadhara Samhita by taking 16 times water and reduced to $1 / 8^{\text {th}}$. The kwātha sieved and filtered to remove all the drug particles and reduced in low flame with $15 \%$ of talc (IP grade) to get a uniform dried solid mass. Then it was powdered and stored in an airtight container.

\section{Animal}

Wistar strain albino rats of either sex between 150-250g body weights were obtained from the animal house attached to the Department of Pharmacology, SDM Centre for Research in Ayurveda and Allied Sciences, Udupi, Karnataka, India following approval of synopsis on 29/05/2017 (Approval No: SDMCRA/IAEC/KT-DG-01). The animals were fed with normal rat diet and water ad libitum throughout the study period. They were acclimatized in the laboratory condition for two weeks before the study. The housing conditions: controlled lighting of $12: 12 \mathrm{~h}$ light and dark cycle, the temperature of $25{ }^{\circ} \mathrm{C}$ and relative humidity of about $50 \%$.

\section{Study design}

Twelve rats were selected, which were separated into 2 groups. Each rat was kept in separate metabolic cages after proper labeling for identity. The rats were weighed and the group was named as Group A-Control group, Group B-Test group. Each rat from two groups was kept in separate cages provided with a constant amount 
of water and food per day. To each rat $200 \mathrm{ml}$ of water and $100 \mathrm{~g}$ food were provided in the food hopper and bottle holder per day. After $24 \mathrm{~h}$ the amount of left-over water and food was measured to obtain the quantity of water and food consumed per day, this was recorded for consecutive $5 \mathrm{~d}$ without administering the drug to the rats in both groups. On the sixth day onwards the test drug was administered at the dose of $200 \mathrm{mg} / \mathrm{kg}$ body weight to the test group and the same procedure was repeated for 10 more days. Quantity of stool and urine was measured every day. On every alternative day, the weight of each rat from all the groups was noted. The parameters recorded for each rat on a day were, food consumption, water ingestion, faecal output (wet fecal-immediate after collection and dry fecal-after keeping in hot air oven for $105^{\circ} \mathrm{C}$ temperature for $4 \mathrm{~h}$ ), faecal water (wet faecal weight-dry faecal weight), urine output and food conversion ratio [Food consumption (divided by) dry faecal weight per day] both in Absolute value and relative value.

\section{Statistical analysis}

All the values were expressed as MEAN \pm SEM (standard error of the mean) and the data were analyzed by the unpaired-test and pairedtest. A level of $\mathrm{P}<0.05$ was considered statistically significant. The level of significance was noted and interpreted accordingly.

\section{RESULTS}

Table 1: Effect of Bridelia stipularis (L.) Blume on food consumption with data presented in terms of absolute value

\begin{tabular}{llll}
\hline Group & \multicolumn{4}{l}{ Food consumption in $\mathbf{g} / \mathbf{1 0 0} \mathbf{g}$ body } & & \\
\cline { 2 - 4 } & Preliminary phase mean $\pm \mathbf{s e m}$ & Therapeutic phase mean \pm sem & (absolute value) \\
\hline Control & $18.14 \pm 0.79$ & $15.23 \pm 0.60$ & -- \\
Test drug & $15.68 \pm 0.52$ & $16.67 \pm 0.36$ & $9.46 \uparrow$ \\
\hline
\end{tabular}

$\mathrm{n}=6$, The expressions were calculated by taking mean \pm standard error to the mean $\mathrm{p}$-value less than 0.05 was counted as significant in comparison to control

Table 1 shows after administering the test drug, food intake in gm/d was increased by $9.46 \%$ in the test group when compared to the control group; however, that increased data were statistically not significant.

Table 2: Effect of Bridelia stipularis (L.) blume on food consumption with data presented in terms of relative value

\begin{tabular}{llll}
\hline Group & \multicolumn{4}{l}{ Food consumption in $\mathbf{g} \mathbf{1 0 0} \mathbf{g}$ body weight (relative value) } \\
\cline { 2 - 4 } & Preliminary phase mean \pm sem & Therapeutic phase mean \pm sem & \% Change \\
\hline Control & $7.06 \pm 0.28$ & $6.30 \pm 0.17$ & - \\
Test drug & $6.13 \pm 0.26$ & $6.60 \pm 0.35$ & $4.76 \uparrow$ \\
\hline
\end{tabular}

$\mathrm{n}=6$, The expressions were calculated by taking mean \pm standard error to the mean $\mathrm{p}$-value less than 0.05 was counted as significant in comparison to control

Table 2 shows after administering the test drug, food intake in $\mathrm{gm} / \mathrm{d}$ was increased by $4.76 \%$ in the test group when compared to the control group; however, that increased data were statistically not significant.

Table 3: Effect of Bridelia stipularis (L.) blume on water consumption with data presented in terms of absolute value

\begin{tabular}{lll}
\hline \multirow{2}{*}{ Group } & Water consumption in $\mathbf{~ m l} \mathbf{1 0 0}$ g body weight (absolute value) \\
\cline { 2 - 3 } & Preliminary phase mean \pm sem & Therapeutic phase mean \pm sem \\
\hline Control & $31.80 \pm 0.96$ & $21.58 \pm 0.91$ \\
Test drug & $26.7 \pm 0.64$ & $26.27 \pm 1.03^{* *}$ \\
\hline
\end{tabular}

$\mathrm{n}=6$, the expressions were calculated by taking mean \pm standard error to the mean ${ }^{* *}$-value less than 0.01 was counted as highly significant in comparison to control

Table 3 shows after the administration of the test drug, water intake in $\mathrm{ml} / \mathrm{d}$ were increased by $21.73 \%$ in the test group when compared to the control group; the observed increase was statistically significant at the level of $\mathrm{P}<0.01$.

Table 4: Effect of Bridelia stipularis (L.) blume on water consumption with data presented in terms of relative value

\begin{tabular}{llll}
\hline Group & \multicolumn{4}{l}{ Water intake in $\mathbf{m l} / \mathbf{1 0 0}$ g body weight (relative value) } & \% Change \\
\cline { 2 - 4 } & Preliminary phase mean \pm sem & Therapeutic phase mean \pm sem & -- \\
\hline Control & $12.46 \pm 0.31$ & $8.63 \pm 0.53$ & $20.97 \uparrow$ \\
Test drug & $11.04 \pm 0.56$ & $10.44 \pm 0.74$ & \\
\hline
\end{tabular}

$\mathrm{n}=6$, The expressions were calculated by taking mean \pm standard error to the mean $\mathrm{p}$-value less than 0.05 was counted as significant in comparison to control

Table 4 shows after the administration of the test drug, water intake in $\mathrm{ml} / \mathrm{d}$ were increased by $20.97 \%$ in the test group when compared to the control group; however, that increased data were statistically not significant. 
Table 5: Effect of Bridelia stipularis (L.) blume on urine output with data presented in terms of absolute value

\begin{tabular}{lll}
\hline \multirow{2}{*}{ Group } & \multicolumn{2}{l}{ Urine output in ml/100 g body weight (absolute value) } \\
\cline { 2 - 3 } & Preliminary phase mean \pm sem & Therapeutic phase mean \pm sem \\
\hline Control & $6.68 \pm 0.52$ & $4.22 \pm 0.46$ \\
Test drug & $5.47 \pm 0.38$ & $5.56 \pm 0.70$ \\
\hline
\end{tabular}

$\mathrm{n}=6$, the expressions were calculated by taking mean \pm standard error to the mean p-value less than 0.05 was counted as significant in comparison to control

Table 5 shows after the administration of the test drug urine output in $\mathrm{ml} / \mathrm{d}$ were increased by $31.75 \%$ in the test group when compared

to the control group; however, that increased data were statistically not significant.

Table 6: Effect of Bridelia stipularis (L.) Blume on urine output with data presented in terms of relative value

\begin{tabular}{lll}
\hline Group & \multicolumn{2}{l}{ Urine output in ml/100 g body weight (relative value) } \\
\cline { 2 - 3 } & Preliminary phase mean \pm sem & Therapeutic phase mean \pm sem \\
\hline Control & $2.75 \pm 0.29$ & $2.26 \pm 0.56$ \\
Test drug & $2.26 \pm 0.20$ & $2.19 \pm 0.28$ \\
\hline
\end{tabular}

$\mathrm{n}=6$, The expressions were calculated by taking mean \pm standard error to the mean p-value less than 0.05 was counted as significant in comparison to control.

Table 6 shows after the administration of the test drug urine output in $\mathrm{ml} / \mathrm{d}$ were decreased by $31.75 \%$ in the test group when compared to the control group; however, decreased data were statistically not significant.

Table 7: Effect of Bridelia stipularis (L.) blume on the faecal matter (wet) with data presented in terms of absolute value

\begin{tabular}{lll}
\hline Group & Faecal matter (wet) in $\mathbf{g} / \mathbf{1 0 0}$ g body weight (absolute value) \\
\cline { 2 - 3 } & Preliminary phase mean \pm sem & Therapeutic phase mean \pm sem \\
\hline Control & $7.47 \pm 0.33$ & $7.09 \pm 0.54$ \\
Test drug & $9.32 \pm 0.72$ & $9.22 \pm 0.52^{*}$ \\
\hline
\end{tabular}

$\mathrm{n}=6$, The expressions were calculated by taking mean \pm standard error to the mean * p-value less than 0.05 was counted as significant in comparison to control

Table 7 shows after the administration of the test drug wet faecal output in gm/d was a $30.04 \%$ increase in the test group compared to the control group. The increased data were statistically significant ('P' value less than 0.05 ).

Table 8: Effect of Bridelia stipularis (L.) blume on the faecal matter (wet) with data presented in terms of relative value

\begin{tabular}{lll}
\hline Group & \multicolumn{1}{l}{ Faecal matter (wet) in $\mathbf{g} / \mathbf{1 0 0}$ g body weight (relative value) } \\
\cline { 2 - 3 } & Preliminary phase mean \pm sem & Therapeutic phase mean \pm sem \\
\hline Control & $3.48 \pm 0.18$ & $3.3 \pm 0.11$ \\
Test drug & $3.83 \pm 0.33$ & $3.64 \pm 0.24$ \\
\hline
\end{tabular}

$\mathrm{n}=6$, the expressions were calculated by taking mean \pm standard error to the mean p-value less than 0.05 was counted as significant in comparison to control.

Table 8 shows after administration of the test drug wet faecal output in $\mathrm{gm} / \mathrm{d}$ was a $10.30 \%$ increase in the test group compared to the control group; however, that increased data were statistically nonsignificant.

Table 9: Effect of Bridelia stipularis (L.) blume on the faecal matter (dry) with data presented in terms of absolute value

\begin{tabular}{llll}
\hline Group & \multicolumn{4}{l}{ Dry faecal matter in $\mathbf{g} / \mathbf{1 0 0} \mathbf{g}$ body weight (absolute value) } & \% Change \\
\cline { 2 - 4 } & Preliminary phase mean $\pm \mathbf{s e m}$ & Therapeutic phase mean \pm sem & -- \\
\hline Control & $4.29 \pm 0.23$ & $3.79 \pm 0.14$ & $26.39 \uparrow$ \\
Test drug & $4.96 \pm 0.30$ & $4.79 \pm 0.15^{* * *}$ & \\
\hline
\end{tabular}

$\mathrm{n}=6$, the expressions were calculated by taking mean \pm standard error to the mean $* * *$ p-value less than 0.001 was counted as extremely significant in comparison to control

Table 9 shows after the administration of the test drug, dry faecal output in $\mathrm{gm} / \mathrm{d}$ was a $26.39 \%$ increase in the test group when compared to the control group. The increased data were statistically significant at the level of $\mathrm{P}<0.001$. 
Table 10: Effect of Bridelia stipularis (L.) blume on the faecal matter (dry) with data presented in terms of relative value

\begin{tabular}{llll}
\hline Group & \multicolumn{4}{l}{ Dry faecal matter in $\mathbf{g} / \mathbf{1 0 0} \mathbf{g}$ body weight (relative value) } & \%Change \\
\cline { 2 - 4 } & Preliminary phase mean $\pm \mathbf{s e m}$ & Therapeutic phase mean \pm sem & -- \\
\hline Control & $1.78 \pm 0.09$ & $1.56 \pm 0.06$ & $20.51 \uparrow$ \\
Test drug & $2.04 \pm 0.13$ & $1.88 \pm 0.12^{*}$ & \\
\hline
\end{tabular}

$\mathrm{n}=6$, the expressions were calculated by taking mean \pm standard error to the mean, ${ }^{*} \mathrm{p}$-value less than 0.05 was counted as significant in comparison to control

Table 10 shows after the administration of the test drug, dry faecal output in $\mathrm{gm} / \mathrm{d}$ was a $20.51 \%$ increase in the test group compared to the control group. The increased data were statistically significant.

Table 11: Effect of Bridelia stipularis (L.) blume on faecal water with data presented in terms of absolute value

\begin{tabular}{lll}
\hline \multirow{2}{*}{ Group } & \multicolumn{1}{l}{ Faecal water in ml/100 g body weight (absolute value) } \\
\cline { 2 - 3 } & Preliminary phase mean \pm sem & Therapeutic phase mean \pm sem \\
\hline Control & $4.23 \pm 0.16$ & $4.29 \pm 0.24$ \\
Test drug & $4.46 \pm 0.46$ & $4.47 \pm 0.0 .24$ \\
\hline
\end{tabular}

$\mathrm{n}=6$, the expressions were calculated by taking mean \pm standard error to the mean $\mathrm{p}$-value less than 0.05 was counted as significant in comparison to control

Table 11 shows after the administration of the test drug, faecal water in $\mathrm{ml} / \mathrm{d}$ was a $4.2 \%$ increase in the test group compared to the control group. The increased data were statistically nonsignificant

Table 12: Effect of Bridelia stipularis (L.) blume on faecal water with data presented in terms of relative value

\begin{tabular}{lll}
\hline Group & \multicolumn{1}{l}{ Faecal water in ml/100 g body weight (relative value) } \\
\cline { 2 - 3 } & Preliminary phase mean \pm sem & Therapeutic phase mean \pm sem \\
\hline Control & $1.66 \pm 0.06$ & $1.74 \pm 0.08$ \\
Test drug & $1.80 \pm 0.21$ & $1.79 \pm 0.14$ \\
\hline
\end{tabular}

$\mathrm{n}=6$, the expressions were calculated by taking mean \pm standard error to the mean p-value less than 0.05 was counted as significant in comparison to control

Table 12 shows after administration of the test drug, faecal water in $\mathrm{ml} / \mathrm{d}$ was a $2.87 \%$ increase in the test group compared to the control group. The increased data were statistically nonsignificant.

Table 13: Effect of Bridelia stipularis (L.) blume on food conversion ratio with data presented in terms of absolute value

\begin{tabular}{llll}
\hline Group & Food conversion ratio (absolute value) & & \\
\cline { 2 - 4 } & Preliminary phase mean \pm sem & Therapeutic phase mean \pm sem & \% Change \\
\hline Control & $4.28 \pm 0.36$ & $4.29 \pm 0.18$ & - \\
Test drug & $3.17 \pm 0.08$ & $3.62 \pm 0.13^{*}$ & $15.62 \downarrow$ \\
\hline
\end{tabular}

$\mathrm{n}=6$, the expressions were calculated by taking mean \pm standard error to the mean *p-value less than 0.05 was counted as significant in comparison to control

Table 13 shows after the administration of the test drug, the food conversion ratio in absolute value was significantly
$(15.62 \% \downarrow)$ decreased in the test group compared to the control group.

Table 14: Effect of Bridelia stipularis (L.) blume on food conversion ratio with data presented in terms of relative value

\begin{tabular}{llll}
\hline Group & Food conversion ratio (relative value) & & \% Change \\
\cline { 2 - 4 } & Preliminary phase mean \pm sem & Therapeutic phase mean \pm sem & \\
\hline Control & $3.51 \pm 0.19$ & $4.40 \pm 0.19$ & $15.68 \downarrow$ \\
Test drug & $3.18 \pm 0.08$ & $3.71 \pm 0.21^{* *}$ & \\
\hline
\end{tabular}

$\mathrm{n}=6$, the expressions were calculated by taking mean \pm standard error to the mean ${ }^{* *}$-value less than 0.01 was counted as highly significant in comparison to control

Table 15: Effect of Bridelia stipularis (L.) blume on body weight

\begin{tabular}{lll}
\hline Group & Change in body weight (mean \pm sem) & \% change \\
\hline Control & $1.34 \pm 1.13$ & -- \\
Test drug & $3.96 \pm 1.74$ & $1.96 \uparrow$ \\
\hline
\end{tabular}

$\mathrm{n}=6$, the expressions were calculated by taking mean \pm standard error to the mean p-value less than 0.05 was counted as significant in comparison to control. 
Table 14 shows after the administration of the test drug, the food conversion ratio in relative value were significantly $(15.68 \% \downarrow)$ decreased in the test group compared to the control group.

Table 15 shows after the administration of the test drug, an increase in body weight were observed in the test group compared to the control group. However, the increased data were statistically not significant.

\section{DISCUSSION}

The quality or attributes obtained after the completion of the digestion of food or drug are known as vipaka. There is a difference in opinion about the number of vipäkas. The most accepted one is Trividha Vipākavāda (three types of vipāka) which includes Madhura vipāka, Amla vipāka and Katu vipāka [6]. The effect of vipāka on the body is elaborately explained by Ācarya Caraka. He clearly explained the effect of each vipāka on dośa, dhātu, and mala. At dośa level, madhura vipaka is kapha vardhaka, amla vipāka is pitta vardhaka whereas kațu vipāka is vātā vardhaka in nature. At dhatu level, madhura vipāka may act as śukravardhaka and amla and kațu vipāka act as sukranaśana. In the formation of mala, madhura and amla vipāka causes sruștavinmutrata whereas kațu vipāka results in badhavi țmutrata [7].

During the experimental study, food intake, water intake, faecal wet, faecal dry, faecal water, and urine output were noted as increased. A significant increase in the faecal wet and dry matter along with an increase in faecal water shows the easy evacuation of faeces. This total effect may be considered as sristavinmūtrata (loose and easy evacuation of the bowel) which is the action of both Madhura vipāka and Amla vipāka. Madhura vipāka is guru and śukrala i. e Responsible for an increase in body weight and increased spermatogenesis. On the other hand; Amla vipāka is just the opposite of it, responsible for decreased spermatogenesis and body weight. In this study in the test drug group, the bodyweight of the rats also increased suggests the action of sweet metabolic transformation.

On a preliminary analysis of rasa (Taste) and virya (active potency) as per available method (SC Dhyani; 2003), it was observed that leaves of the drug Bridelia stipularis have Kașāya pradhāna Tikta rasa (astringent and bitter taste) and sita virya (cold potency). This indicates that the leaves of the test drug may be a vicitrapratyayārabdha (an unusual combination of pancamahābhūtas). However, according to Parāśara Acharya, Kasāya and Tikta rasa can be Madhura vipāka [8]. Hence it cannot be taken as vicitrapratyayarabdha (an unusual combination of pancamahābhūtas). Pittaghna property of the leaves of B. stiplaris also suggests the probability of Madhura Vipāka.

The increase in food intake noted as $4.76 \%$ and that of faecal dry matter was $20.51 \%$. i.e. the percentage increase in food intake is less when compared with the faecal output. This shows that the drug has some dipana effect and has no pācana property. This is also clear from the status of food conversion ratio and change in body weight. Because bodyweight increased only by $2 \%$ and FCR (food conversion ratio) was decreased by $15 \%$ which means faecal output is greater than food consumption.

\section{CONCLUSION}

It is high time to explore the ayurvedic pharmacological properties of extra-pharmacopoeial drugs using available methods which will lend a hand to fend off the problems faced by the Ayurveda community. Based on the preliminary assessment it may be concluded that the drug Bridelia stipularis (L.) Blume possess Madhura vipaka (Sweet metabolic transformation). To further substantiate the finding, clinical evaluation can be conducted to include it in scientific Ayurveda practice.

\section{ACKNOWLEDGMENT}

The authors are grateful to Dr. P. B Benil, Professor, Deparment of Agadatantra, V. P. S. V Ayurveda College, Kottakkal for his immense help in statistical works.

\section{FUNDING}

Nil

\section{AUTHORS CONTRIBUTIONS}

All the authors have contributed equally.

\section{CONFLICT OF INTERESTS}

\section{Declared none}

\section{REFERENCES}

1. Shahrear Biozid, Mohammad Nazmul Alam, Ferdous Alam, Ashraful Islam, Hasibur Rahman. A comparative study of thrombolytic effects of methanolic extract of Bridelia stipularis and Aglaonema hookerianum leaf. Pharma Innovation J 2015;4:5-7.

2. Bhandary MJ, Chandrashekar KR. Herbal therapy for herpes in the ethnomedicine of coastal Karnataka. Indian J Traditional Knowledge 2011;10:528-32.

3. Oratai N, Patcharin S, Kornkanok Y, Narumon S. A survey of medicinal plants in mangrove and beach forests from peninsula, songkhla province, Thailand. J Med Plant Res 2012;6:2421-37.

4. Vagbhata Laghu. Ashtanga Hridaya. (Sarvangasundara commentary of arunadatta). Pt. Harisadasiva Sastri Paradakara editor. Varanasi: Chaukhamba Sanskrit Samsthan; Reprint; 2011. p. 169.

5. Dhyani SC. Rasa-pancaka ayurvrdic principle of drug action. $2^{\text {nd }}$ ed. Varanasi, India: Chaukhamba Krishnadas Academi Publisher; 2003. p. 76-80.

6. Bidhan Mahajon, Ravi Shankar B, Remadevi R. Assessment 'vipaka'(metabolism) of a new medicinal plant in an animal model. Global J Res Med Plants Indigen Med 2014;11:434.

7. Atreyabhadrakapiyamadhyaya: Vaidya Jadavaji Trikamji. Charaka Samhita: Sootrasthana. Varanasi: Chowkhambha Sanskrit Series; 2014. p. 146.

8. Dravyadi Vijnaniya Adhyaya, KR Sreekantha Moorthy. Ashtanga sangraha of vagbhata: sootrasthana. 8th ed. Varanasi: Chaukhamba Orientalia; 2004. p. 326. 